Article

\title{
The Role of Infrastructure for Electric Passenger Car Uptake in Europe
}

\author{
Anastasios Tsakalidis * $*$, Andreea Julea $@$ and Christian Thiel $@$ \\ European Commission, Joint Research Centre (JRC), 21027 Ispra, Italy; andreea.julea@ec.europa.eu (A.J.); \\ christian.thiel@ec.europa.eu (C.T.) \\ * Correspondence: anastasios.tsakalidis@ec.europa.eu; Tel.: +39-0332-785907
}

Received: 21 October 2019; Accepted: 13 November 2019; Published: 15 November 2019

\begin{abstract}
Plug-in electric vehicles (PEV) can be a main lever towards a decarbonised road transport system. The PEV market uptake needs to be nurtured by appropriate support measures for users, for technological advances related to the vehicle and its components, and for all relevant recharging infrastructure deployment. This paper focuses on the role of PEV recharging infrastructure for electric passenger car uptake in Europe. It examines the status of road transport electrification, relevant policies, incentives and national plans. We find that the status and plans of PEV and recharging infrastructure and the corresponding support measures vary significantly between countries. The PEV share in the various analysed countries ranged in 2017 from $0.01 \%$ to $5.49 \%$ and is estimated to reach values between $0.05 \%$ and $12.71 \%$ in 2020 . The corresponding ratio of PEV per one publicly accessible recharging point ranged between 1 and 60 and is estimated to vary between 3 and 161 in 2020 . Diverging plans could lead to market fragmentation in the European Union (EU) and impede the EU-wide circulation of PEVs. The appropriate level of recharging infrastructure should be determined to both support PEV deployment and to prevent sunk investments. Different country experiences vis-à-vis PEV and infrastructure support could be useful to identify best practices.
\end{abstract}

Keywords: transport electrification; recharging infrastructure; incentives; transport policies

\section{Introduction}

The transition to a low-carbon economy is one of the key priorities for the European Union (EU) and since transport is still one of the main $\mathrm{CO}_{2}$ and pollutant emitters, its decarbonisation is key to achieving this. The large dependency of the sector on fossil fuel is a major barrier towards this aim, a fact that has financial and environmental implications, affecting the EU. In 2017, the average $\mathrm{CO}_{2}$ emissions from new cars increased for the first time since 2010 [1]. The introduction of low and zero emission vehicles could be one of the catalysing factors supporting transport decarbonisation and the mitigation of the environmental impacts of internal combustion engines and traditional mobility solutions [2]. Even though figures show that electric vehicles have been continuously increasing their market share and have turned from a niche market in the early 2010s to a considerable market in several countries, the transition to electro-mobility is still neither full-scale, nor easy to achieve [3].

In spite of the increasing market penetration, barriers for plug-in electric vehicle (PEV) mass market uptake remain since consumers tend to be concerned about specific electro-mobility characteristics that can act as a restraining factor, including the purchase costs, depreciation, driving range, number of models offered, and finally recharging infrastructure availability. The aforementioned characteristics are related to vehicle development, apart from the last one that is related to the supporting infrastructure. The latter has a key role for prospective PEV customers since sufficient and reliable recharging infrastructure increases confidence that Battery Electric Vehicles (BEVs) will reliably meet their travel 
needs and help reduce range anxiety, a factor affecting user acceptance of PEVs [4,5]. This paper focuses on the role of infrastructure in electric passenger car uptake in Europe.

\section{Relevant Research and Policy Background}

Electro-mobility and its components constitute a domain that has been covered by numerous research and innovation initiatives and studies. Moreover, a series of policies have been adopted that form the framework for an accelerated deployment of alternative fuels (AF) and especially electrified road transport vehicles and their recharging infrastructure.

\subsection{Research on PEV Infrastructure Aspects}

Various infrastructure-related aspects of electro-mobility have been covered during the past years by research activities and scientific papers. The relevant research can be clustered in the following categories:

Technical issues: Lucas et al. (2018) [6] developed an indicator-based methodology for assessing PEV recharging infrastructure which was also used to evaluate public policies related to PEV recharging infrastructure use and rollout. Moreover, Lucas et al. (2015) [7] examined the grid harmonic impact of PEV fast recharging, highlighting that fast chargers' connection limit is set by harmonic limits and not only by power. Trentadue et al. (2018) [8] studied the efficiency of PEV fast recharging under extreme temperatures, confirmed the declared efficiency values by manufacturers at ambient temperature and reported lower energy efficiencies at extreme temperatures.

Interoperability and standardisation: Hardy et al. (2013) [9] examined the role of the twinned interoperability centres in the EU and the United States of America (USA) towards a harmonised approach in standardisation of both PEVs and their recharging infrastructure. Ferwerda et al. (2018) [10] consider that the absence of widely adopted protocols and interoperability standards for charging could hinder the development of cross-border PEV travel ("e-roaming") and they present a set of basic functionalities e-roaming should have. Based on best practices of six years of e-roaming in the Netherlands, they propose piloting e-roaming on a European level using open standards.

Optimal placement and type: The optimal allocation and type of recharging infrastructure and their impact to address slow and fast recharging needs, both within an area and along highways, were evaluated using various methodologies. Cai et al. (2014) [11] used taxi fleet big data informed travel patterns for siting public PEV recharging stations. Guo and Zhao (2015) [12] used a fuzzy technique for order of preference by similarity to ideal solution (TOPSIS) based on the sustainability perspective for optimal PEV recharging station site selection. Ji et al. (2015) [13] presented a tool used to estimate fast charger demand and sample results on a current and future BEV scenario, highlighting the data and methods required for fast charger demand planning. Huang et al. (2016) [14] proposed two optimisation models for fast and slow recharging points placement for minimising the total cost while satisfying a certain coverage goal, eliminating the partial coverage problem and providing better results compared to the complementary partial coverage method. Zhu et al. (2016) [15] developed a model for dealing with the recharging station location problem in terms of recharging station siting and number of chargers per station using genetic algorithms. Gong et al. (2016) [16] proposed an abstract-map-based, multi-layer strategy to optimally plan public fast recharging stations, taking into account conditions of the transport system, the power system and their integration towards an integrated planning. Jochem et al. (2016) [17] extended the flow-refuelling location model (FRLM) and applied it along the German highway, focusing on the inclusion of the closest network node access distance. Yi and Bauer (2016) [18] presented models for optimally placing recharging stations in urban areas, maximising the reachable households and minimising overall e-transportation energy cost. Gkatzoflias et al. (2016) [19] introduced a Geographic Information System (GIS) methodology, based on open source tools aimed to support national authorities to allocate recharging stations in urban environments, rural road networks and highways. Reuter-Oppermann et al. (2017) [20] compared two applied approaches, a coverage-oriented and an optimisation-based method to estimate the 
number and allocation of fast recharging stations along highways. Gagarin and Corcoran (2018) [21] proposed to model the facility location problem of recharging stations in road networks as a multiple domination problem on reachability graphs. Vazifeh et al. (2019) [22] proposed a methodology to perform data-driven optimisation of PEV recharging station locations using pervasive mobility data.

Optimal PEV per recharging point ratios: Indications on average electric vehicle/publicly accessible recharging point ratios have been provided by the National Development and Reform Commission of China (2015) [23], the International Energy Agency (2017) [24], Cooper and Schefter (2017) [25], Wood et al. (2017) [26] and Harrison and Thiel (2017) [27], with values ranging from 7 to 27 PEVs per public recharging point. Gnann et al. (2018) [28] estimated that public fast recharging points (RPs) can be similar to other alternative fuels at 1000 vehicles per one point (for a power level of $150 \mathrm{~kW}$ ). Moreover, the National Renewable Energy Laboratory and the California Energy Commission (2017) [29] developed a dedicated Electric Vehicle Infrastructure Projection Tool (EVI-Pro).

Grid and generation capacity impact: The potential impacts of PEVs and the transition to electro-mobility on the grid was studied by Pasaoglu et al. (2013) [30] confirming that uncontrolled recharging could cause artificial electricity-demand spikes when certain time windows for lower tariffs exist network-wide. De Gennaro et al. (2014) [31] studied the urban fleet electrification impact on the grid regarding both additional electric energy demand and its geographical distribution. Loisel et al. (2014) [32] assessed strategies for vehicle-to-grid (V2G) and grid-to-vehicle (G2V) schemes. De Gennaro et al. (2015) [33] studied a customer-driven recharging infrastructure design and V2G in urban areas showing that a V2G interaction strategy can contribute to daily electric energy demand reductions reaching $50 \%$.

Flammini et al. (2019) [34], analysing an extensive real data set on PEVs charging behaviour from the Netherlands in 2015, based on a Beta Mixture Model developed to represent the multimodal probability distributions of the relevant variables due to the drivers' behaviour, presented results referring to $\mathrm{G} 2 \mathrm{~V}$ and provided indications on the potential of $\mathrm{V} 2 \mathrm{G}$ application. When V2G is allowed, the charging behaviour might change depending on the grid connection options and on the revenues for V2G service provision. Hafez and Bhattacharya (2017) [35] focused on the recharging station optimal design aiming at minimising lifecycle cost considering environmental emissions. Tsakalidis and Thiel (2018) [36] calculated that a 15\% PEV share of the total EU car stock would lead to an additional power demand of roughly $95 \mathrm{TWh}$ or $3 \%$ of the total projected electricity demand in 2030 . The power peak could potentially increase by $20 \mathrm{GW}$ or $3-4 \%$ of the projected peak load in the same year. This could be mitigated by enabling load shift or even V2G options. Nevertheless, fast recharging stations at selected service areas along the major EU highways could potentially lead to the need of local grid reinforcements in order to accommodate up to $20 \mathrm{MW}$ peak power at times of intense traffic.

User perception: The attitude of car drivers towards PEVs and conventional vehicles, PEV driving patterns and drivers' behaviour was investigated by Thiel et al. (2012) [37], showing that car drivers perceive an adequate network of recharging infrastructure as crucial. Donati et al. (2015) [38] analysed individual driving patterns for conventional and PEVs, assessing whether behaviours differ, with data suggesting that PEVs are driven for shorter distances and duration. The real-driving energy consumption was found approximately $38 \%$ higher than the type-approved, while the energy consumed was considerably dependent on the ambient temperature. Gómez Vilchez et al. (2017) [4] quantified the factors influencing people's car type choices in Europe, with the results proving that lack of recharging infrastructure is one of the main reasons for buyers not choosing PEVs and highlighting the need for related policies supporting transport electrification.

Policy impact: On the policy side, Thiel et al. (2019) [39] analysed the impact of recharging infrastructure deployment efforts in the EU on climate/energy and air quality targets as well as employment. Thiel et al. (2016) [40] studied the role of electro-mobility under a stricter alternative emissions legislative framework within the EU showing that compared to the current legislation, a stricter target of $70 \mathrm{~g} \mathrm{CO}_{2} / \mathrm{km}$ for cars by 2030 could reduce total transport $\mathrm{CO}_{2}$ emissions by $5 \%$ and oil dependence by more than $2 \%$. Harrison and Thiel (2017) [27] studied the potential policy interventions 
to stimulate vehicle technology, highlighting the major interactions between different powertrain types and with recharging infrastructure provision. Lévay et al. (2017) [41] examined the impact of PEV cost on vehicle market and the role of fiscal incentives to increasing PEV sales providing comparison of the total cost of ownership of PEVs. Tsakalidis and Thiel (2018) [36] examined the status of PEV in the EU between 2010 and 2017, presenting also the status of recharging infrastructure and relevant policies and incentive schemes that have been supporting the transition to electro-mobility in a series of European countries. Hardman (2019) [42] studied the impact of reoccurring and non-financial incentives on PEV adoption, including infrastructure development incentives highlighting the potential positive effect of recharging infrastructure availability to PEV adoption.

\subsection{Policy Context Development}

At European level, according to the Directive 2014/94/EU on the deployment of Alternative Fuels Infrastructure (AFI), Member States (MS) are required to ensure, by means of their National Policy Frameworks (NPF), that an appropriate number of publicly accessible recharging and refuelling points will be rolled out, with main focus on urban and suburban agglomerations and the Trans-European Transport Network (TEN-T) Core Network. The Directive requires from MS interoperable publicly accessible infrastructure solutions and the setting of future targets covering electricity, compressed natural gas (CNG), liquefied natural gas (LNG), hydrogen and liquefied petroleum gas (LPG) [43]. In 2015, the European Commission (EC) adopted the Energy Union Package committing to the development of a strategy towards a low-carbon competitive economy. To this aim, a certain electrification of European transport is needed and, according to EU policy documents, should be accompanied by a European leading role in terms of electro-mobility and energy storage technologies [44].

The EC with its Communication "Towards an Integrated Strategic Energy Technology (SET) Plan: Accelerating the European Energy System Transformation" (COM(2015)6317) has as one of its core priorities to diversify and strengthen energy options for sustainable transport including strengthening market take-up of renewable fuels needed for sustainable transport solutions [45]. In the European Strategy for Low-Emission Mobility (COM(2016)501), the roll-out of infrastructure for alternative fuels is highlighted as a basic element for scaling up the use of low-emission alternative energy for transport [46]. In the "Accelerating Clean Energy Innovation" (COM(2016)763) Communication, the EC intended to focus future funding available under the EU's research and innovation (R\&I) framework programme "Horizon 2020" more clearly on four interconnected strategic priorities including electro-mobility and a more integrated urban transport system featuring an innovative recharging infrastructure [47]. In 2017, the Strategic Transport Research and Innovation Agenda (STRIA) towards a clean, connected and competitive mobility was published, presenting seven transport R\&I roadmaps on seven key focus areas, including transport electrification [48]. Finally, in the Communication "A Clean Planet for all: A European strategic long-term vision for a prosperous, modern, competitive and climate neutral economy" (COM(2018)773), it is underlined that transitions in the transport sector will require accelerated deployment of relevant infrastructure, increased synergy between transport and energy systems with smart recharging or refuelling stations that enable seamless, cross-border services [49].

\subsection{Analysis of the Policy Impact on Recharging Infrastructure and PEV Uptake}

The level of deployment and the type of recharging infrastructure are important elements related to the development of electro-mobility. The recharging infrastructure presents variations both in level of development but also technologically across Europe. Policy frameworks at national level have been developed targeting this domain. The purpose of this paper is to examine the role of infrastructure in electric passenger car uptake in Europe through the analysis of relevant policies and NPFs, the levels of passenger car market penetration in Europe and by extension the promotion of electro-mobility as alternative to conventional motorised mobility. To this aim, NPFs from MSs of the EU and similar 
plans for the European Free Trade Association (EFTA) countries Iceland, Norway and Switzerland are examined.

\section{Materials and Methods}

As a first step, recharging infrastructure data necessary for the analysis were collected focusing on the status, future targets and timelines according to the NPFs. For present data, a series of relevant sources can be used including the European Alternative Fuels Observatory (EAFO), the International Energy Agency (IEA), the European Environment Agency (EEA) etc.

The next step includes the selection and development of indicators that were used for the assessment of the results. The indicators had to match the policy context and goals that have been set at European and national level.

We propose two indicators, which allow comparison of markets of different sizes, recharging infrastructure in terms of RPs per 100,000 vehicles and PEV deployed per 100,000 vehicles (where vehicles are the sum of passenger cars and light commercial vehicles). We believe these indicators using normalisation with the total vehicle fleet are better suited than the ones using population since we were considering PEV as a type of vehicle. We also presented and analysed the recharging infrastructure using a ratio of number of PEVs per RP, a metric that offers additional input to characterise the electro-mobility situation of a certain geographic area allowing also a better analysis of differences across different markets.

The optimal number of publicly accessible RPs depends on several factors like travel patterns, number of PEVs (and more precisely number of BEVs and plug-in hybrid electric vehicles), number of PEV owners with a dedicated private RP (dictated by housing type) and with workplace RPs access [50]. In this study, we focused on the indicator number of PEVs. We also analysed the percentages of different RP charging rate types and the link with their location that is influenced by the parking time.

At national level, support measures have been used in many countries as levers for developing electro-mobility, but their focus areas and implementation levels vary. Support measures affect both the infrastructure deployment and PEV market uptake perspectives. We propose a classification of support measures that contains five categories, each of them with several sub-categories, as presented in Table 1. A detailed description of the sub-categories is provided in Appendix A.

In the main step of the methodology, the data collected at the previous steps were analysed: they were normalised according to the total vehicle fleet of each country, missing data gaps were filled via inter/extrapolations using available data. All relevant visualisations were produced per indicator selected.

The final step includes the assessment of the results and the output production. The figures and visuals produced through data analysis were assessed based on the selected indicators. The assessment results were used to formulate the outputs that characterise the status of PEV recharging infrastructure, successful and challenging implementation cases, future prospects and potential for improvements. The results of this process can be used as inputs for the potential update of the policy objectives and potential policy appraisal.

Figure 1 presents the steps and processes used to examine the role of recharging infrastructure in PEV uptake in Europe through the analysis of relevant policies, infrastructure deployment status and vehicle uptake. 
Table 1. Proposed classification of support measures.

\begin{tabular}{|c|c|}
\hline Support Measures Categories & Sub-Categories \\
\hline $\begin{array}{l}\text { Acquisition incentives (AI) } \\
\text { (incentives affecting the vehicle purchase, that are } \\
\text { effective in influencing purchasing decisions }[51,52] \text { ) }\end{array}$ & $\begin{array}{l}\text { Purchase incentives (possibly differentiated on } \mathrm{CO}_{2} \\
\text { emission level) } \\
\text { Reduced loan interest for acquisition } \\
\text { Public procurement incentives } \\
\text { Purchase tax reduction/exemption } \\
\text { Registration tax reduction/exemption } \\
\text { Import tax reduction/exemption } \\
\text { Income tax reduction } \\
\text { Scrappage for replacement schemes } \\
\text { VAT tax reduction/exemption } \\
\text { Conversion cost credit } \\
\text { Bonus/malus schemes } \\
\text { Other }\end{array}$ \\
\hline $\begin{array}{l}\text { Recurring financial incentives (operational) (RFI) } \\
\text { (fiscal policies affecting the cost of ownership and use, } \\
\text { generating financial advantages for consumers [51]) }\end{array}$ & $\begin{array}{l}\text { Annual circulation/ownership/road tax } \\
\text { reduction/exemption } \\
\text { Free recharging } \\
\text { Fuel tax reduction } \\
\text { Road tolls reduction/exemption } \\
\text { Congestion or low/zero emission zone charges } \\
\text { reduction/exemption } \\
\text { Parking incentive } \\
\text { Reduced VAT on leasing } \\
\text { Other }\end{array}$ \\
\hline $\begin{array}{l}\text { Recurring non-financial incentives (RNFI) } \\
\text { (operational non-financial benefits for PEVs and } \\
\text { recharging infrastructure use [52]) }\end{array}$ & $\begin{array}{l}\text { Parking priorities } \\
\text { Restricted lane use } \\
\text { Access in low/zero emission zones } \\
\text { Other (education, demo, information, outreach programs) }\end{array}$ \\
\hline Infrastructure incentives (II) [52] & $\begin{array}{l}\text { Incentives to install RPs for home/business use } \\
\text { Charging facilities for PEVs }\end{array}$ \\
\hline $\begin{array}{l}\text { Company-specific incentives (CSI) } \\
\text { (leading to benefits for companies and their } \\
\text { employees, facilitating investments in clean } \\
\text { technology, and making these investments partially } \\
\text { deductible from corporate and income taxes [52-55]) }\end{array}$ & $\begin{array}{l}\text { Benefit-in-kind taxation } \\
\text { Capital allowance } \\
\text { Salary sacrifice } \\
\text { Extra depreciation rule } \\
\text { VAT deduction } \\
\text { Annual circulation/ownership/road tax } \\
\text { reduction/exemption } \\
\text { Other }\end{array}$ \\
\hline
\end{tabular}

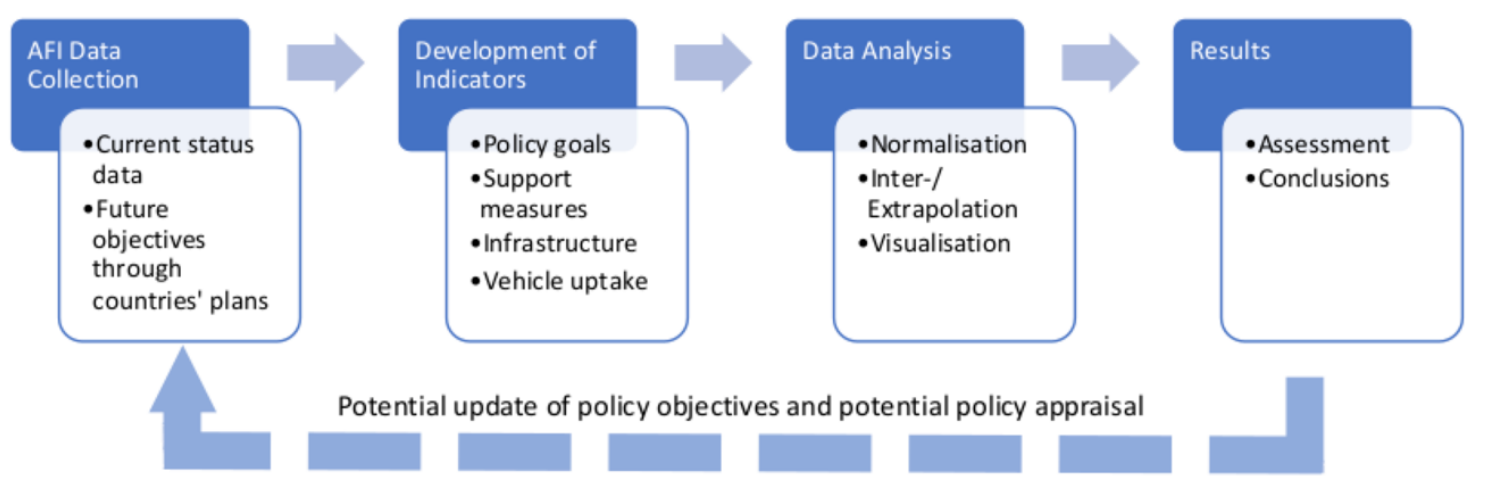

Figure 1. Methodological steps of the analysis.

The following section presents the results of applying this methodology for Europe, covering the EU-28 and 3 EFTA countries. In this study, we use for the EU MSs the future targets as presented in their NPFs and for the EFTA countries future values derived from their published electro-mobility strategies. 


\section{Results of the Analysis: Status and Expectations on Recharging Infrastructure in Europe}

The successful uptake of PEVs depends largely on consumer buy-in, which is facilitated, amongst others, by an easy access to the recharging infrastructure and its affordability. Enabling consumers to experience mobility seamlessly is therefore a key requirement. Developing dedicated recharging infrastructure will encourage more people to purchase PEVs. In consequence, countries should target the deployment of this infrastructure in an ambitious balanced way. The AFI Directive gives an indicative sufficiency ratio $\left(\mathrm{I}_{\text {suff }}\right)$ of 10 PEVs per one publicly accessible $\mathrm{RP}$, where:

$$
\mathrm{I}_{\text {suff }}=\text { PEV number/RP number }
$$

The analysis of the NPFs shows that 26 out of 28 MSs (except Spain and Sweden) provided targets for publicly accessible RPs for 2020 and that electricity is the preferred alternative fuel for passenger cars in most MSs [56].

Table 2 presents the support measures, classified as previously described, in the EU MSs and three EFTA countries (Norway, Iceland and Switzerland).

Table 2. Support measures for electro-mobility in Europe [2,51,52,57].

\begin{tabular}{|c|c|c|c|c|c|c|}
\hline Country & Code & $\begin{array}{l}\text { Acquisition } \\
\text { Incentives }\end{array}$ & $\begin{array}{l}\text { Recurring Financial } \\
\text { Incentives }\end{array}$ & $\begin{array}{l}\text { Recurring Non-Financial } \\
\text { Incentives }\end{array}$ & $\begin{array}{c}\text { Infrastructure } \\
\text { Incentives }\end{array}$ & $\begin{array}{l}\text { Company-Specific } \\
\text { Incentives }\end{array}$ \\
\hline $\begin{array}{l}\text { Austria } \\
\text { Belgium }\end{array}$ & $\begin{array}{l}\mathrm{AT} \\
\mathrm{BE}\end{array}$ & & & & & \\
\hline $\begin{array}{l}\text { Dulgaria } \\
\text { Bula }\end{array}$ & & & & & & \\
\hline $\begin{array}{c}\text { Switzerland } \\
\text { Cyprus }\end{array}$ & $\begin{array}{l}\mathrm{CH} \\
\mathrm{CY}\end{array}$ & & & & & \\
\hline Czechia & $\mathrm{CZ}$ & & & & & \\
\hline Germany & DE & & & & & \\
\hline Denmark & DK & & & & & \\
\hline Estonia & EE & & & & & \\
\hline Greece & $\begin{array}{l}\text { EL } \\
\text { FS }\end{array}$ & & & & & \\
\hline $\begin{array}{l}\text { Finland } \\
\text { Finlo }\end{array}$ & FI & & & & & \\
\hline France & $\mathrm{FR}$ & & & & & \\
\hline Croatia & HR & & & & & \\
\hline Hungary & $\mathrm{HU}$ & & & & & \\
\hline Ireland & IE & & & & & \\
\hline $\begin{array}{l}\text { Iceland } \\
\text { Italy }\end{array}$ & IS & & & & & \\
\hline Lithuania & $\begin{array}{l}\text { LT } \\
\text { LT }\end{array}$ & & & & & \\
\hline Luxembourg & $\mathrm{LU}$ & & & & & \\
\hline Latvia & & & & & & \\
\hline $\begin{array}{c}\text { Malta } \\
\text { Netherlands }\end{array}$ & $\begin{array}{l}\text { MT } \\
\text { NL }\end{array}$ & & & & & \\
\hline Norway & NO & & & & & \\
\hline $\begin{array}{l}\text { Poland } \\
\text { Polngan }\end{array}$ & $\begin{array}{l}\mathrm{PL} \\
\mathrm{PT}\end{array}$ & & & & & \\
\hline $\begin{array}{l}\text { Portugal } \\
\text { Romania }\end{array}$ & RO & & & & & \\
\hline $\begin{array}{l}\text { Sweden } \\
\text { Swen }\end{array}$ & SE & & & & & \\
\hline $\begin{array}{l}\text { Slovenia } \\
\text { Slyankia }\end{array}$ & SI & & & & & \\
\hline $\begin{array}{l}\text { Slovakia } \\
\text {. }\end{array}$ & SK & & & & & \\
\hline United Kingdom & & & & & & \\
\hline & $\begin{array}{l}\text { Planned f } \\
\text { Present ar } \\
\text { Past and } \mathrm{C}\end{array}$ & $\begin{array}{l}\text { the future } \\
\text { planned for tl } \\
\text { continued }\end{array}$ & uture & & & \\
\hline
\end{tabular}

The table provides an overall picture at country level for the past, current and future planned policies supporting electro-mobility. A full list of the countries considered in this analysis and their respective country codes is included in the table.

Looking at the categories of measures, one of the most important categories, from the user point of view, is illustrated by the Acquisition Incentives (AI). Several studies state that they are a significant determining factor in the purchase of a PEV [50]. Almost all countries considered AI, with six exceptions. BG, HR and LT never introduced them, EE stopped them, while LV and PL intend to introduce them in the future; these MSs are in the incipient situation of electro-mobility development.

For Recurring Financial Incentives (RFI), the situation appears better; only EE and LT have not introduced any RFI and PL has future introduction plans. These MSs are also at an early stage of electro-mobility development. The situation is heterogeneous for Recurring Non-Financial Incentives 
(RNFI). Some of the countries which already display higher shares of PEVs (CH, IS and LU) have not introduced RNFIs, while some of the countries at an earlier stage of PEV deployment (CY, PL, RO and SI) plan to introduce them in the future. Among the advanced countries, only DE does not have RNFI, but has decided to adopt them in the future.

For Infrastructure Incentives (II), the situation is much diversified from a temporal point of view. Six countries already stopped them, and seven countries with still low PEV shares have not yet introduced IIs but plan to introduce them in the future. The category of Company-Specific Incentives (CSI) is less populated, where especially countries with higher shares of PEV are present.

Based on the country coverage level of the table, it can be seen that the countries with higher PEV shares (FR, NL, NO, SE, UK) have introduced all measure categories. Some countries, which are still at an earlier stage of PEV deployment, manifest an ambition to cover all support measures, such as LV, ES and PT.

For the following diagrams, instead of absolute values for PEV and RP that are influenced by the population level (giving the well-known top five, NO, UK, DE, NL and FR for PEV fleet, and NL, DE, FR, UK and NO for RP), we used their normalised values by the total vehicle fleet. We consider that this relative indicator allows comparison between countries and offers a more realistic presentation.

Figure 2 presents the European status at the end of 2017 in terms of publicly accessible PEV recharging infrastructure differentiated by power and normalised by the total fleet of vehicles.

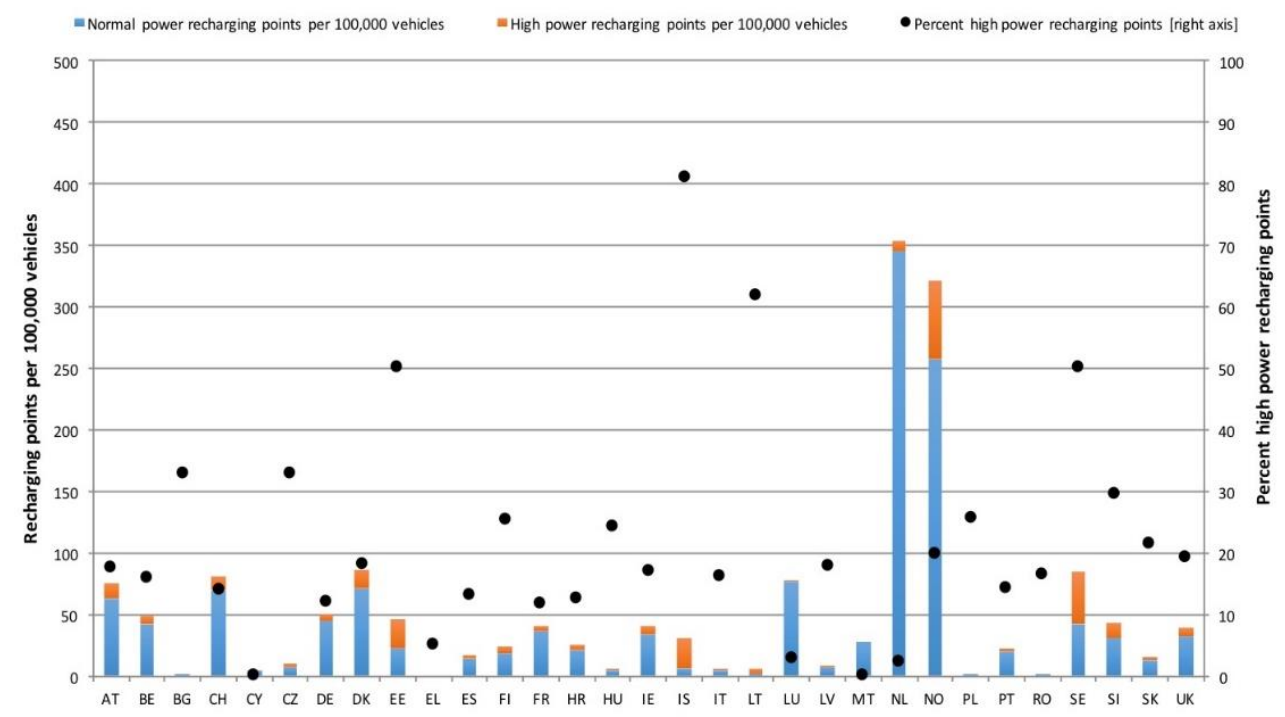

Figure 2. Status of publicly accessible recharging points per 100,000 vehicles across Europe (2017) (own elaboration on data from [57]).

For making possible a meaningful evolution analysis, the year 2017 was selected as a reference year compared to the 2020 planned values transmitted in the National Policy Frameworks submitted by the EU member states. It represents the year after which started the implementation of the NPFs that were assessed in [56].

According to the categorisation introduced in the AFI Directive, normal power RPs (NPRP) offer up to $22 \mathrm{~kW}$ of power, whereas high power RPs (HPRP) offer more than $22 \mathrm{~kW}$. In the future, due to technological development and increased power of the RPs, there will be a need to define several sub-categories for the current high power recharging infrastructure category.

Regarding the number of publicly accessible RPs reported per 100,000 vehicles, the first two positions belong to NL and NO, countries recognised as frontrunners in the field and having the highest PEV shares in Europe. Instead, their percentages of HPRPs remain quite modest linked to their early PEV introduction and deployment of recharging infrastructure. Denmark, the third in this top group, already stopped II measures (see Table 2). The highest HPRP percentages (exceeding 
$50 \%)$ are observed in the cases of advanced IS and SE but also beginners EE and LT. Other high HPRP percentage values (exceeding 20\%) express recent electro-mobility developments despite the low level of PEV motorisation, as is the case of countries like BG, CZ, HU, PL, SI and SK.

Figure 3 presents the planned situation of publicly accessible recharging infrastructure in 2020 as presented in the NPFs of the MSs and strategies of the EFTA countries.

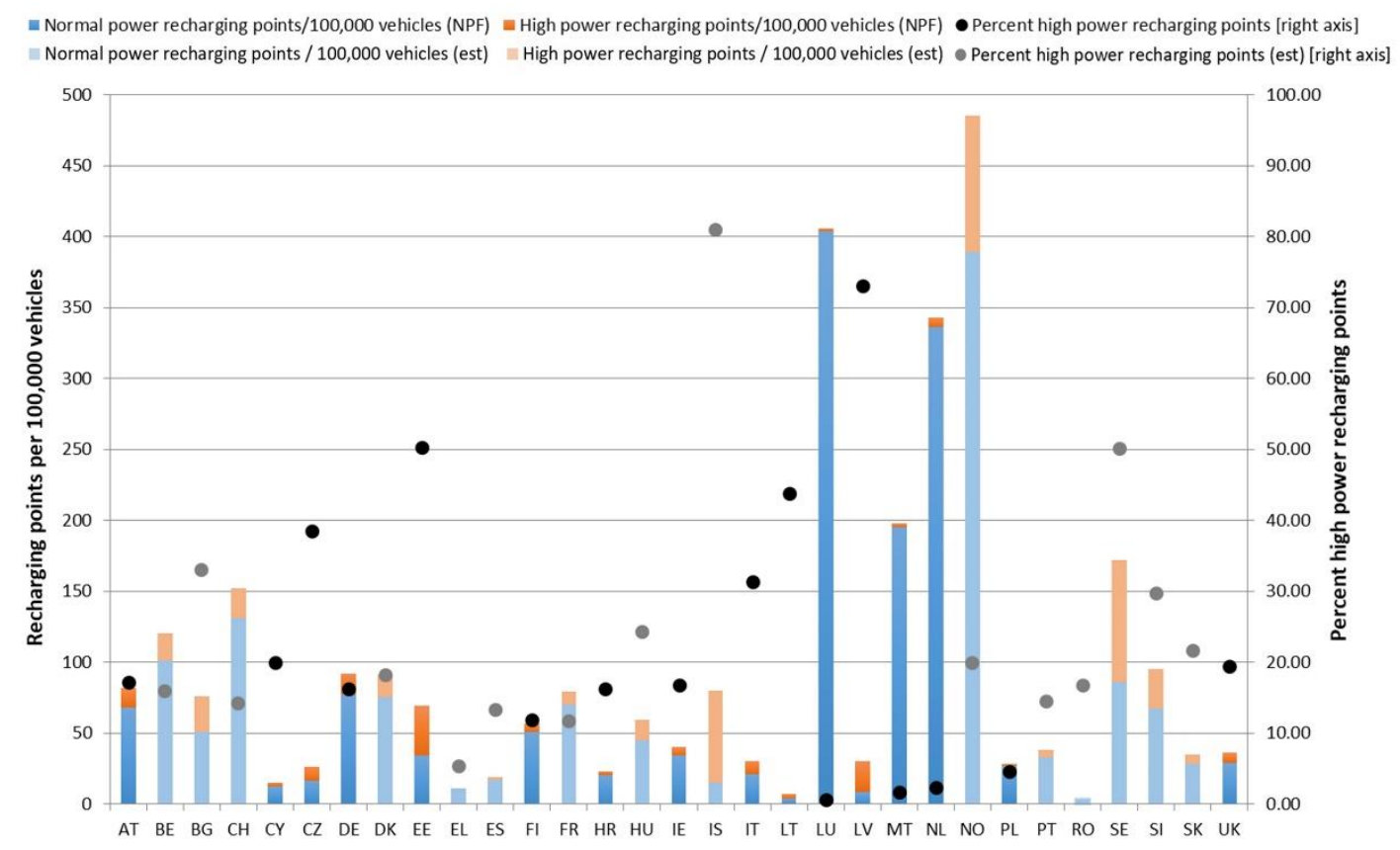

Figure 3. Overview of publicly accessible recharging points per 100,000 vehicles across Europe (2020) according to countries' strategies (own elaboration on National Policy Framework (NPF) data from [58]).

In the case of the countries where future recharging infrastructure targets were not available (ES and SE that did not provide them in their NPFs and CH, IS and NO, the three EFTA countries studied), we performed a linear extrapolation assuming the same number of new RP will be built per year as in 2018.

According to the figure, the frontrunners with respect to the number of RP normalised by the total vehicle fleet remain NO and NL, the group being completed by LU that appears very ambitious (all three countries presenting values superior to 300 RPs per 100,000 vehicles and having assumed II support measures, see Table 2). In the case of LU, we highlight the fact that all the new RP planned in the NPF will be NPRP which leads to a very low percentage of HPRP $(<1 \%)$. In contrast, LV foresees only HPRP to be built in the future. Only 16 countries provided a differentiation between NPRP and HPRP for their future infrastructure targets. For the rest of the MSs, we assumed that the current percentage of HPRP would be kept also in the future (displayed in lighter colour tones in Figure 3). The overall level of ambition of the countries for recharging infrastructure is quite low, five MSs (HR, IE, LT, NL, and UK) have already overachieved their 2020 total RP targets at the end of 2017 and therefore we kept the 2017 infrastructure values constant for 2020. For HPRP, six countries (AT, FI, IE, LT, LU and UK) have surpassed their 2020 targets at the end of 2017 and we have again considered the 2017 HPRP values also for 2020. Compared with the 2017 situation, the average percentage of HPRP in 2020 is planned to reach $16.24 \%$ from $13.51 \%$ (it increases in seven countries-CY, CZ, DE, HR, IT, LV, MT). The ambitious foreseen increases in recharging infrastructure of BE, BG, IT, LU, LV, and PL are credible being supported by their decision to use II support measure (see Table 2). In the case of HU and MT, their RP targets may be seen as overly optimistic as both countries have stopped this type of support measure. 
Figure 4 gives a European overview of the existing and future situation of PEVs in relation to the RPs, both variables being normalised by the total national vehicle fleet in the case of the 14 most ambitious countries with respect to the foreseen PEV share in the total fleet in 2020 (PEV share > 1\%). The main graph represents the magnified version of the grey area from the smaller framed graph in the bottom right part.

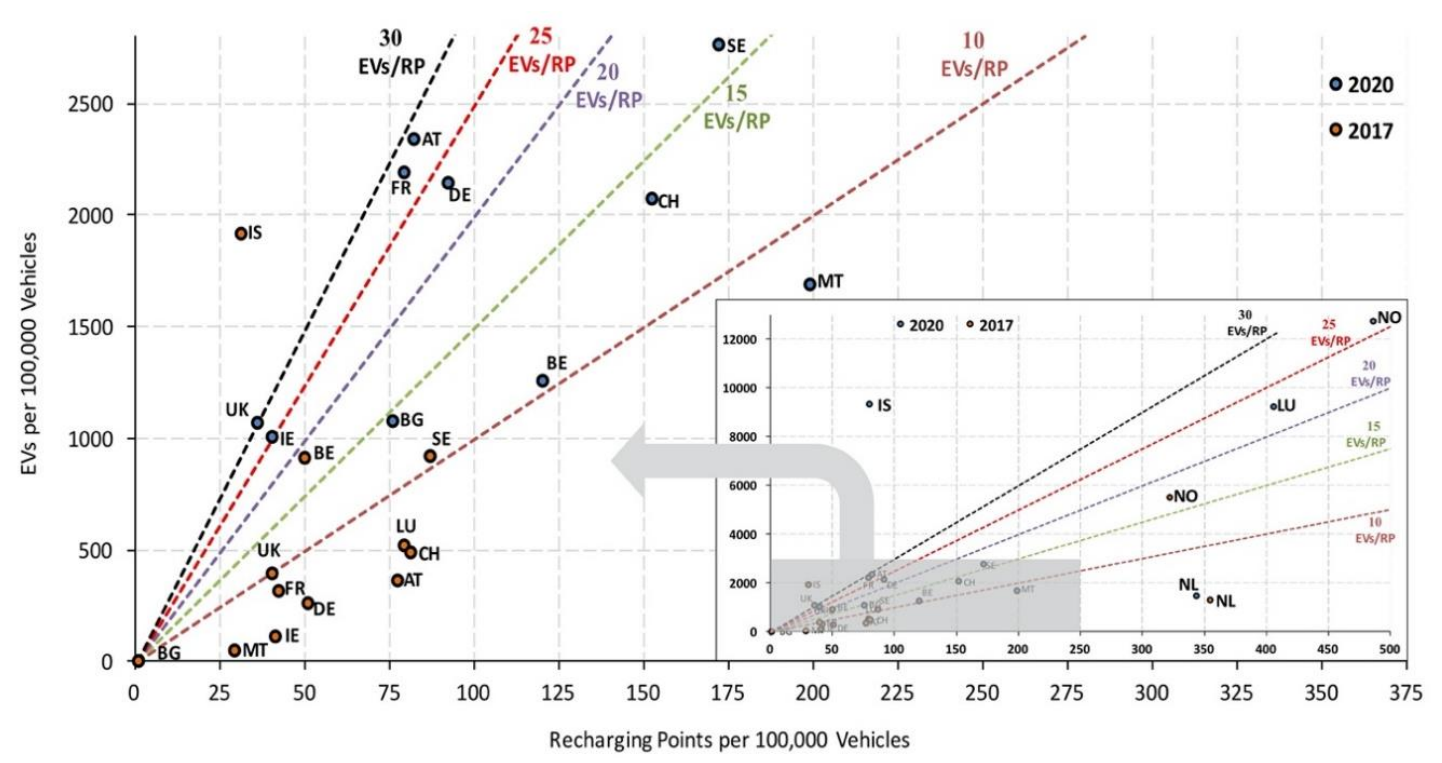

Figure 4. Current and future situation of plug-in electric vehicles (PEVs) and publicly accessible recharging points normalised by total vehicle fleet across Europe (own elaboration on data from European Alternative Fuels Observatory (EAFO) [57] and NPF [58]).

Since three EU MSs (EE, HR, RO) did not provide estimations of future PEV fleet in 2020 but provided RP targets, in those cases we considered a PEV fleet using their RP future targets and the ratio of $10 \mathrm{PEVs} / \mathrm{RP}$ indicated in the AFI Directive as sufficient. In the case of $\mathrm{CH}$, IS and NO, where we also did not have PEV fleet values estimated by the countries for 2020, we performed a linear interpolation on the shares of PEV new registrations. For that we used public commitments of the countries in order to compute the PEV fleet in 2020 (CH-10\% market share in 2020, IS-100\% market share in 2030, NO-100\% market share in 2025). For SE, where PEV fleet estimation and RP target for 2020 were not available, we calculated the future PEV fleet by linear extrapolation of the PEV market share assuming the same yearly growth as in 2018 .

We can observe quite divergent approaches in terms of anticipated electro-mobility development. Substantial increases of PEV deployment are observed for the majority of these countries. High PEV percentage increases (with more than $500 \%$ growth) are projected for small countries as AT, BG, CH, IE, LU and MT that could be more convenient for PEV introduction because of shorter domestic daily travel distances, but also for larger and more advanced countries in the field as DE and FR. Generally, these impressive increases seem to be sustained by corresponding support measures (see Table 2). In the case of BG and IE, their objectives have to be regarded with reluctance because some support measure categories are absent (AI and CSI for BG, and RNFI and CSI for IE). Despite having all support measures categories, UK and PT are not so enthusiastic with their future objectives.

Regarding the total publicly accessible RP number normalised by the vehicle fleet, the percentage increases are not so ambitious. The highest increases of more than $400 \%$ are encountered for small countries like BG and MT that are found at incipient stages of electro-mobility deployment and for LU, a relative advanced country in this field. Concerning the advanced countries, FR, DE, NO and SE have increases between 50\% and 100\%. NL and UK show even slight decreases since their 2020 RP targets were overachieved already in 2017 and their values of 2017 were kept constant for 2020 while 
the total PEV fleet is expected to grow. It is noteworthy to mention that in NL most consumers do not have home charging access and they park their vehicles on the street. This fact explains the high value of publicly accessible RP per 100,000 vehicles (country with best situation in 2017) and the quite low $\mathrm{PEVs} / \mathrm{RP}$ ratio (inferior to 10). For all countries presented in the diagram (with the exception of MT), the targets are credible due to assumed II measures (see Table 2).

In Figure 4, recharging infrastructure sufficiency index $\mathrm{I}_{\text {suff }}$ regions (the inclined dashed lines from the origin of the graph indicate the borders of these regions) can be also observed. In 2017, the majority of the displayed European countries have ratios of less than $10 \mathrm{PEV}$ per publicly accessible RP (10 countries are clustered under the orange line indicating $10 \mathrm{PEVs} / \mathrm{RP}$ ).

For the foreseen situation in 2020, the PEV share increases are usually accompanied by a deterioration in terms of $\mathrm{I}_{\text {suff }}$ (for 11 countries $\mathrm{I}_{\text {suff }}$ increases and changes region, for two countries (NL, MT) it stays in the same region and only for one (BE) it decreases). If the future RP targets are reached and the PEV estimates materialise in 2020, only three countries (BE, MT and NL) would have a PEVs/RP ratio inferior to 10 which is the value indicated as sufficient by the AFI Directive [43]. The most substantial increases are noticed in the cases of AT, FR, IE and UK for which $\mathrm{I}_{\text {suff }}$ evolves from below $10 \mathrm{PEVs} / \mathrm{RP}$ to above $25 \mathrm{EVs} / \mathrm{RP}$. In these countries, a careful monitoring of the PEV market development would be indicated in order to keep the deployment of recharging infrastructure synchronised with the increasing number of PEVs on the roads.

Figure 4 also reveals that NO, globally the leading country in PEV market share, has a value of $\mathrm{I}_{\text {suff }}$ of around 18 in 2017 and 27 in 2020 (visible in the smaller framed graph showing the situation without a zoom as in the main graph). This is a countrywide average and in specific areas, the index can be even higher. However, in Figenbaum and Kolbenstvedt (2015) [59] it is stated that 75\% of households have private parking and charging in NO, which makes the situation not so critical at national level.

HPRP are primarily needed along the TEN-T network and highways; not in the cities and sub-urban areas. We performed an analysis in which we assumed that $70 \%$ of the HPRP in 2020 will be distributed in the service areas on the travel corridors (highways/TEN-T Core Network) while the remaining $30 \%$ at different points of interest in urban areas where the parking duration is short (e.g., restaurants, coffee shops, shopping malls). We computed the number of service areas needed to cover the highways/TEN-T Core Network (assuming a homogeneous spatial coverage on one direction of the road at every $60 \mathrm{~km}$ ). In the case of the three EFTA countries that do not have a TEN-T Core Network, we considered for it the length of the highway network. Then, we distributed the planned HPRP to these resulted service areas and we obtained an average number of HPRP corresponding to one service area for each country.

These average numbers of HPRP per service area for 2020 are displayed in Figure 5 for the case of the highways (left map) and TEN-T Core Network (right map). In both cases, the best situation with the highest number of HPRP per service area is noticed for SE, IS and NO in the Northern part of the continent. A better situation for central European countries is in the case of HPRP distribution on TEN-T Core Network, which is generally more reduced that the highway network in these countries. An inverse situation is visible in the case of eastern European countries, for which the TEN-T Core Network is more extended than the highway one. For the countries illustrated in red with less than 10 HPRP per service area (some eastern European countries, ES, PT and IE), the situation needs to be improved. Especially in ES and PT, congestion and high waiting times are likely to occur on travel corridors in the peak touristic periods, which can have a negative impact on the tourism in those areas. 


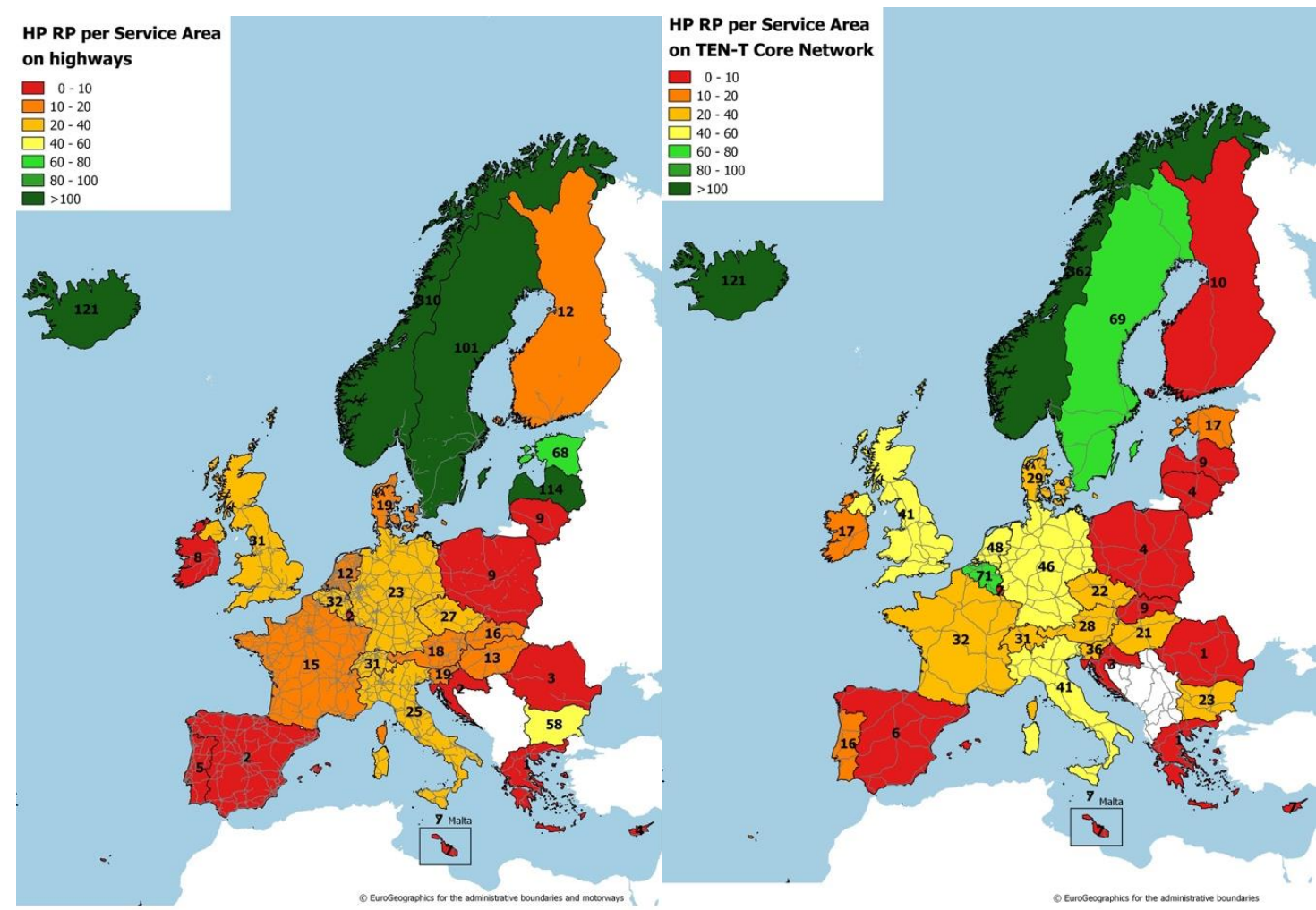

Figure 5. Average number of high power recharging points (HPRP) per ideally situated service areas on highways and Trans-European Transport Network (TEN-T) Core Network across Europe in 2020 (own elaboration on NPF data [58] and strategies of European Free Trade Association (EFTA) countries [60-62]).

\section{Discussion and Conclusions}

The plans (NPFs) are not coherent at European level since their level of ambition varies greatly across countries (e.g., PEV estimated shares for 2020 range between $0.06 \%$ and $12.71 \%$ of the vehicles total fleet). Our analysis shows that the plans of the European countries, with around 220,000 publicly accessible RPs by 2020 (an increase of about $65 \%$ from the situation at the end of 2017) is insufficient to meet an $I_{\text {suff }}$ of 10, recommended by Directive 2014/94/EU. The ratio of PEVs per publicly accessible RPs will deteriorate in almost all European countries (from an average of seven PEVs/RP to $18 \mathrm{PEVs} / \mathrm{RP}$ in 2020 at the level of the studied countries). A careful monitoring of the PEV market development would be opportune for keeping the deployment of recharging infrastructure synchronised with the increasing number of PEVs on the roads.

Support policies and the introduction of incentive schemes in many countries are instrumental in boosting PEV market uptake and, in consequence, the transition to a low emission mobility. A notable increase in PEV registrations and market shares has been observed in European countries that have introduced incentives and support measures, while countries without or with limited similar schemes present low figures. The useful experiences and insights derived from the analysis of the various European support schemes and their impacts can be used to guide the implementation and further development of NPFs. Comparing the countries' forecasts with the corresponding existing support measures, the level of their credibility can be assessed. In addition, more research is needed in order to better understand the link between support policies and consumer acceptance of PEVs.

Nevertheless, not all countries have a long-term strategy and planning for PEV recharging infrastructure. Additionally, support measures stimulating PEV demand across the EU MSs are not harmonised, a fact that has led to a certain market fragmentation both in terms of PEVs on the road and publicly accessible recharging infrastructure availability. The HPRPs ( $>22 \mathrm{~kW})$ share varies 
significantly between MSs. Currently, on average every $10^{\text {th }}$ publicly accessible RP in the EU supports fast recharging above $22 \mathrm{~kW}$. A lack of publicly accessible RPs observed in some European cases might have negatively affected consumer confidence in PEVs, highlighting the need for availability, accessibility and interoperability of publicly available RPs.

Generally, fast recharging points are primarily needed along the TEN-T Core Network and highways and not in the cities or sub-urban areas. The TEN-T network requires appropriate coverage and in this article we focused on the geographic aspect regarding maximum distance in between recharging points. Other aspects that could influence the allocation of the fast recharging points on these types of roads, that we plan to investigate in the future, relate to the amount of traffic and the electric grid accessibility and characteristics. Motorisation rates and vehicle fleets in each country are different and should be taken into account when planning and assessing infrastructure needs.

Another important element is the further deployment of private recharging infrastructure that will complement the publicly available infrastructure. On the policy side, Directive (EU) 2018/844 on the Energy Performance of Buildings regulates the mandatory share of recharging points in the parking spaces of new buildings. Nevertheless, at the moment, private infrastructure is characterised by lack of data and a standardised monitoring mechanism. The use of various sources including data from censuses, electricity providers, PEV manufacturers, recharging equipment manufacturers could be a good starting point for the development of such a mechanism.

In both cases, there is a need for a standardised infrastructure availability monitoring system for optimised data collection and to avoid miscalculations (such as in the double counting in the case of RPs with two different connectors in the Netherlands).

Recharging infrastructure has evolved in terms of numbers of publicly accessible RPs but also in terms of recharging speed, in line with the late technological advances. This fast pace of development calls for a structured redefinition of infrastructure needs according to technological advances in recharging infrastructure and for planning and reallocation according to new technologies. Within this framework, an updated classification of charging power or rate categories is required, following technological advancement in charging equipment.

A European interoperable network of recharging infrastructure, including both NPRPs and HPRPs, is required in order for PEVs to achieve higher market penetration along with the required standardisation to ensure interoperability of the recharging infrastructure. Fast recharging using power above $50 \mathrm{~kW}$ and even beyond $300 \mathrm{~kW}$ and the deployment of technologies related to wireless recharging, vehicle to grid integration, e-roaming and all relevant communication protocols will be additional levers for the PEV market development.

As wide variations between countries are observed in terms of PEV deployment, publicly accessible infrastructure and the PEV/RP ratios, there is a need to learn from the experiences of the different countries and identify best practices. A careful analysis is needed to determine what reasonable RP introduction numbers would be in order to inform the current debate on the acceptable ratios between vehicles and publicly accessible RPs. This could be informed by further research also via surveys among EV drivers and prospective EV customers.

The overall aim of PEV infrastructure deployment should be to ensure the maintenance and further improvement of current levels of safety, comfort, cost-efficiency and seamless cross-border interoperability for the road network users, towards a cleaner and decarbonised transport system.

Our study focuses on the analysis of key performance indicators, such as PEV penetration and RP deployment at national and European level. While this generates valuable insights for national and European wide strategies and policies, more detailed studies at sub-national level are needed to support decisions at regional and city level. The societal impacts that can be expected from the deployment of PEVs are studied in other papers [39]. In principle, because of a rather comprehensive set-up of EU policies, it can be expected that higher penetration rates of PEVs could even accelerate the decarbonisation of the power sector [40]. 
Author Contributions: Conceptualisation, A.T. and C.T.; methodology, A.T. and A.J.; validation, A.T., A.J. and C.T.; formal analysis, A.T., A.J. and C.T; investigation, A.T., A.J. and C.T.; resources, A.T., A.J. and C.T; data curation, A.J.; writing-Original draft preparation, A.T.; writing-Review and editing, A.J. and C.T.; visualisation, A.T. and A.J; supervision, C.T.

Funding: This research received no external funding.

Acknowledgments: The views expressed here are purely those of the authors and may not, under any circumstances, be regarded as an official position of the European Commission.

Conflicts of Interest: The authors declare no conflict of interest.

\section{Glossary}

\begin{tabular}{|c|c|}
\hline AI & Acquisition Incentives \\
\hline $\mathrm{AF}$ & Alternative Fuels \\
\hline AFI & Alternative Fuels Infrastructure \\
\hline AFV & Alternative Fuel Vehicle \\
\hline BEV & Battery Electric Vehicle \\
\hline CCS & Combined Charging System \\
\hline $\mathrm{CNG}$ & Compressed Natural Gas \\
\hline $\mathrm{CO}_{2}$ & Carbon Dioxide \\
\hline CSI & Company-Specific Incentives \\
\hline EAFO & European Alternative Fuels Observatory \\
\hline $\mathrm{EC}$ & European Commission \\
\hline EEA & European Environment Agency \\
\hline EFTA & European Free Trade Association \\
\hline EU & European Union \\
\hline EVI-Pro & Electric Vehicle Infrastructure Projection Tool \\
\hline FRLM & Flow-Refuelling Location Model \\
\hline G2V & Grid-to-Vehicle \\
\hline GIS & Geographic Information System \\
\hline HPRP & High Power Recharging Point \\
\hline IEA & International Energy Agency \\
\hline II & Infrastructure Incentives \\
\hline $\mathrm{I}_{\text {suff }}$ & Index of Sufficiency ( $\mathrm{I}_{\text {suff }}=$ PEV number $/$ RP number $)$ \\
\hline LNG & Liquefied Natural Gas \\
\hline LPG & Liquefied Petroleum Gas \\
\hline MS & Member State \\
\hline NPF & National Policy Framework \\
\hline NPRP & Normal Power Recharging Point \\
\hline PEV & Plug-in Electric Vehicle \\
\hline R\&I & Research and Innovation \\
\hline RFI & Recurring Financial Incentives \\
\hline RNFI & Recurring Non-Financial Incentives \\
\hline $\mathrm{RP}$ & Recharging Point \\
\hline SET & Strategic Energy Technology \\
\hline STRIA & Strategic Transport Research and Innovation Agenda \\
\hline TEN-T & Trans-European Transport Network \\
\hline TOPSIS & Technique for Order of Preference by Similarity to Ideal Solution \\
\hline USA & United States of America \\
\hline V2G & Vehicle-to-Grid \\
\hline VAT & Value Added Tax \\
\hline
\end{tabular}

\section{Appendix A}

Indicators for AI [51,52].

- Purchase incentives-The client benefits from a grant/bonus/premium when purchasing an alternative fuel vehicle (AFV) that could be differentiated on $\mathrm{CO}_{2}$ emission level. 
- $\quad$ Reduced loan interest-For an AFV acquisition, the client benefits from loan with reduced interest.

- Public procurement incentives-In the case of public institutions fleet or AFI acquisition.

- Purchase tax reduction/exemption.

- $\quad$ Registration tax reduction/exemption-Benefit on registration tax, where AFV may be excluded or pay less than more polluting vehicles, ICEV.

- Import tax reduction/exemption.

- Income tax reduction.

- $\quad$ Scrappage for replacement schemes-Offering a bonus to exchange an old ICEV for a particular kind of new AFV, stimulate consumers to buy low emissions vehicles.

- VAT tax reduction/exemption.

- $\quad$ Conversion cost credit-For transforming an ICEV in an AFV.

- Bonus/malus schemes-The acquisition price may be affected by a subsidy (bonus) for AFV, or by a surcharge (malus) for ICEV, penalising purchases of high-emission vehicles and rewarding low emission vehicles.

- $\quad$ Other-Any other kind of financial decision that may be considered an acquisition incentive.

Indicators for RFI [51].

- Annual circulation/ownership/road tax reduction/exemption-Exemption or reduction for low emission vehicles that pay less than more polluting vehicles (ICEV).

- $\quad$ Free recharging-At some public points.

- $\quad$ Fuel tax reduction/exemption-Fuel duty is applied to transport fuels, but not to electricity [54]; some AF have tax reductions.

- Road tolls reduction/exemption-a toll road (toll way), is a public or private road (almost always a controlled-access highway) for which a fee (or toll) is assessed for passage. It is a form of road pricing typically implemented to help recoup the cost of road construction and maintenance. Using a low emission AFV these fees may be reduced or exempted. This may be extended to ferries, tunnels or bridges.

- Congestion or low/zero emission zone charges reduction/exemption-For AFV and increased fees for ICEV.

- $\quad$ Parking charges reduction/exemption-Free/reduced charges for AFV parking.

- $\quad$ Reduced VAT on leasing AFV.

- $\quad$ Other-Any other kind of financial decisions that may be considered RFI.

Indicators for RNFI [63].

- $\quad$ Parking priorities-Dedicated parking lots for EVs, fixed share for EVs places in parking areas.

- Restricted lane use-Access to bus lanes, to other preferential lanes or to high occupancy vehicle lanes for AFV.

- $\quad$ Access in low/zero emission zones-Where ICEV are prohibited but AFV may access.

- Higher speed limit-For AFV on certain roads.

- $\quad$ Other-any other kind of incentives that may be considered RNFI.

Indicators for II [52].

- Incentives to install recharging points for home/business use.

- $\quad$ Charging facilities for PEVs.

Indicators for CSI [53-55,64].

- Benefit-in-kind taxation-Taxation on private use of company car. Benefit-in-kind is a tax levied on employees who receive advantages in addition to their salary.

- Capital allowance-Enable companies to write down the cost of purchasing cars and vans against taxable profits (e.g., an EV may be eligible for $100 \%$ first year capital allowances, but for a car with higher $\mathrm{CO}_{2}$ emissions only a lower percentage of its cost each year may be written down against the company's taxable profits) [55].

- Salary sacrifice-Scheme allowing employees to sacrifice a portion of their monthly salary in return for a new car. Savings are generated because the employee is no longer liable for income tax on the proportion of the sacrificed salary [53-55].

- Extra depreciation rule-Depreciation allows (or requires) businesses to spread out the cost of long-term assets over the life of the asset. Bonus depreciation for AFVs is a valuable tax-saving tool for businesses. It allows to take an immediate first-year deduction on the purchase of eligible business property, in addition to other depreciation [64].

- VAT deduction-There is VAT deduction on company assets (like AFVs) that are also used for private purposes.

- Annual circulation/ownership/road tax reduction/exemption-Often for low $\mathrm{CO}_{2}$ emitting AFV.

- $\quad$ Public procurement-AFV acquisition for public companies.

- $\quad$ Other-Any other kind of incentives that offer benefits for companies. 


\section{References}

1. European Environment Agency. Monitoring of CO2 Emissions from Passenger Cars-Regulation (EC) No 443/2009. Available online: https://www.eea.europa.eu/data-and-maps/data/co2-cars-emission-14\#tabeuropean-data (accessed on 12 April 2019).

2. Hall, D.; Lutsey, N. Emerging Best Practices for Electric Vehicle Charging Infrastructure; International Council on Clean Transportation: Washington, DC, USA, 2017.

3. Thiel, C.; Krause, J.; Dilara, P. Electric Vehicles in the EU from 2010 to 2014-Is Full Scale Commercialisation Near? Publications Office of the European Union: Luxembourg, 2015.

4. Gómez Vilchez, J.; Harrison, G.; Kelleher, L.; Smyth, A.; Thiel, C.; Lu, H.; Rohr, C. Quantifying the Factors Influencing People's Car Type Choices in Europe: Results of a Stated Preference Survey; Publications Office of the European Union: Luxembourg, 2017.

5. Knupfer, S.M.; Hensley, R.; Hertzke, P.; Schaufuss, P.; Laverty, N.; Kramer, N. McKinsey \& Company Electrifying Insights: How Automakers can Drive Electrified Vehicle Sales and Profitability. Available online: https://www.mckinsey.com/industries/automotive-and-assembly/our-insights/electrifying-insightshow-automakers-can-drive-electrified-vehicle-sales-and-profitability (accessed on 12 April 2019).

6. Lucas, A.; Prettico, G.; Flammini, M.; Kotsakis, E.; Fulli, G.; Masera, M. Indicator-Based Methodology for Assessing EV Charging Infrastructure Using Exploratory Data Analysis. Energies 2018, 11, 1869. [CrossRef]

7. Lucas, A.; Bonavitacola, F.; Kotsakis, E.; Fulli, G. Grid harmonic impact of multiple electric vehicle fast charging. Electr. Power Syst. Res. 2015, 127, 13-21. [CrossRef]

8. Trentadue, G.; Lucas, A.; Otura, M.; Pliakostathis, K.; Zanni, M.; Scholz, H. Evaluation of Fast Charging Efficiency under Extreme Temperatures. Energies 2018, 11, 1937. [CrossRef]

9. Hardy, K.; Bohn, T.; Slezak, L.; Krasenbrink, A.; Scholz, H. US-EU Joint EV-Smart Grid Interoperability Centers. In Proceedings of the 2013 IEEE World Electric Vehicle Symposium and Exhibition (EVS27), Barcelona, Spain, 7-20 November 2013; pp. 1-8.

10. Ferwerda, R.; Bayings, M.; van der Kam, M.; Bekkers, R. Advancing E-Roaming in Europe: Towards a Single "Language" for the European Charging Infrastructure. World Electr. Veh. J. 2018, 9, 50. [CrossRef]

11. Cai, H.; Jia, X.; Chiu, A.S.F.; Hu, X.; Xu, M. Siting public electric vehicle charging stations in Beijing using big-data informed travel patterns of the taxi fleet. Transp. Res. Part D 2014, 33, 39-46. [CrossRef]

12. Guo, S.; Zhao, H. Optimal site selection of electric vehicle charging station by using fuzzy TOPSIS based on sustainability perspective. Appl. Energy 2015, 158, 390-402. [CrossRef]

13. Ji, W.; Nicholas, M.; Tal, G. Electric Vehicle Fast Charger Planning for Metropolitan Planning Organizations: Adapting to Changing Markets and Vehicle Technology. Transp. Res. Rec. J. Transp. Res. Board 2015, 2502, 134-143. [CrossRef]

14. Huang, K.; Kanaroglou, P.; Zhang, X. The design of electric vehicle charging network. Transp. Res. Part D Transp. Environ. 2016, 49, 1-17. [CrossRef]

15. Zhu, Z.; Gao, Z.; Zheng, J.; Du, H. Charging station location problem of plug-in electric vehicles. J. Transp. Geogr. 2016, 52, 11-22. [CrossRef]

16. Gong, L.; Gong, L.; Fu, Y.; Li, Z. Integrated planning of BEV public fast-charging stations. Electr. J. 2016, 29, 62-77. [CrossRef]

17. Jochem, P.; Brendel, C.; Reuter-Oppermann, M.; Fichtner, W.; Nickel, S. Optimizing the allocation of fast charging infrastructure along the German autobahn. J. Bus. Econ. 2016, 86, 513-535. [CrossRef]

18. Yi, Z.; Bauer, P.H. Optimization models for placement of an energy-aware electric vehicle charging infrastructure. Transp. Res. Part E 2016, 91, 227-244. [CrossRef]

19. Gkatzoflias, D.; Drossinos, Y.; Zubaryeva, A.; Zambelli, P.; Dilara, P.; Thiel, C. Optimal Allocation of Electric Vehicle Charging Infrastructure in Cities and Regions; Publications Office of the European Union: Luxembourg, 2016.

20. Reuter-Oppermann, M.; Funke, S.; Jochem, P.; Graf, F. How Many Fast Charging Stations Do We Need Along the German Highway Network? In Proceedings of the EVS30 International Battery, Hybrid and Fuel Cell Electric Vehicle Symposium, Stuttgart, Germany, 9-11 October 2017; pp. 1-11.

21. Gagarin, A.; Corcoran, P. Multiple domination models for placement of electric vehicle charging stations in road networks. Comput. Oper. Res. 2018, 96, 69-79. [CrossRef]

22. Vazifeh, M.M.; Zhang, H.; Santi, P.; Ratti, C. Optimizing the deployment of electric vehicle charging stations using pervasive mobility data. Transp. Res. Part A 2019, 121, 75-91. [CrossRef] 
23. National Development and Reform Commission; Guide to The Development of Electric Vehicle Charging Infrastructure. Available online: http://www.ndrc.gov.cn/zcfb/zcfbtz/201511/t20151117_758762.html (accessed on 12 April 2019).

24. International Energy Agency. Global EV Outlook 2017; IEA: Paris, France, 2017.

25. Cooper, A.; Shefter, K. Plug-in Electric Vehicle Sales Forecast through 2025 and the Charging Infrastructure Required; Institute for Electric Innovation and Edison Electric Institute: Washington, DC, USA, 2017.

26. Wood, E.; Rames, C.; Muratori, M.; Raghavan, S.; Melaina, M. National Plug-In Electric Vehicle Infrastructure Analysis; National Renewable Energy Lab.: Golden, CO, USA, 2017.

27. Harrison, G.; Thiel, C. An exploratory policy analysis of electric vehicle sales competition and sensitivity to infrastructure in Europe. Technol. For. Social Chang. 2017, 114, 165-178. [CrossRef]

28. Gnann, T.; Funke, S.; Jakobsson, N.; Plötz, P.; Sprei, F.; Bennehag, A. Fast charging infrastructure for electric vehicles: Today's situation and future needs. Transp. Res. Part D 2018, 62, 314-329. [CrossRef]

29. National Renewable Energy Laboratory/California Energy Commission; Electric Vehicle Infrastructure Projection Tool (EVI-Pro) Lite. Available online: https://afdc.energy.gov/evi-pro-lite (accessed on 12 April 2019).

30. Pasaoglu, G.; Fiorello, D.; Zani, L.; Zubaryeva, A.; Thiel, C.; Martino, A. Projections for Electric Vehicle Load Profiles in Europe Based on Travel Survey Data; Publications Office of the European Union: Luxembourg, 2013.

31. De Gennaro, M.; Paffumi, E.; Scholz, H.; Martini, G. GIS-driven analysis of e-mobility in urban areas: An evaluation of the impact on the electric energy grid. Appl. Energy 2014, 124, 94-116. [CrossRef]

32. Loisel, R.; Pasaoglu, G.; Thiel, C. Large-scale deployment of electric vehicles in Germany by 2030: An analysis of grid-to-vehicle and vehicle-to-grid concepts. Energy Policy 2014, 65, 432-443. [CrossRef]

33. De Gennaro, M.; Paffumi, E.; Martini, G. Customer-driven design of the recharge infrastructure and Vehicle-to-Grid in urban areas: A large-scale application for electric vehicles deployment. Energy 2015, 82, 294-311. [CrossRef]

34. Flammini, M.G.; Prettico, G.; Julea, A.; Fulli, G.; Mazza, A.; Chicco, G. Statistical characterisation of the real transaction data gathered from electric vehicle charging stations. Electr. Power Syst. Res. 2019, 166, 136-150. [CrossRef]

35. Hafez, O.; Bhattacharya, K. Optimal design of electric vehicle charging stations considering various energy resources. Renew. Energy 2017, 107, 576-589. [CrossRef]

36. Tsakalidis, A.; Thiel, C. Electric vehicles in Europe from 2010 to 2017: Is Full-Scale Commercialisation Beginning? Publications Office of the European Union: Luxembourg, 2018.

37. Thiel, C.; Alemanno, A.; Scarcella, G.; Zubareyeva, A.; Pasaoglu, G. Attitude of European Car Drivers Towards Electric Vehicles: A Survey; Publications Office of the European Union: Luxembourg, 2012.

38. Donati, A.V.; Dilara, P.; Thiel, C.; Spadaro, A.; Gkatzoflias, D.; Drossinos, Y. Individual Mobility: From Conventional to Electric Cars; Publications Office of the European Union: Luxembourg, 2015.

39. Thiel, C.; Julea, A.; Acosta Iborra, B.; De Miguel Echevarria, N.; Peduzzi, E.; Pisoni, E.; Gómez Vilchez, J.J.; Krause, J. Assessing the Impacts of Electric Vehicle Recharging Infrastructure Deployment Efforts in the European Union. Energies 2019, 12, 2409. [CrossRef]

40. Thiel, C.; Nijs, W.; Simoes, S.; Schmidt, J.; van Zyl, A.; Schmid, E. The impact of the EU car $\mathrm{CO}_{2}$ regulation on the energy system and the role of electro-mobility to achieve transport decarbonisation. Energy Policy 2016, 96, 153-166. [CrossRef]

41. Lévay, P.Z.; Drossinos, Y.; Thiel, C. The effect of fiscal incentives on market penetration of electric vehicles: A pairwise comparison of total cost of ownership. Energy Policy 2017, 105, 524-533. [CrossRef]

42. Hardman, S. Understanding the impact of reoccurring and non-financial incentives on plug-in electric vehicle adoption-A review. Transp. Res. Part A Policy Pract. 2019, 119, 1-14. [CrossRef]

43. European Parliament and Council of the European Union. Directive 2014/94/EU of the European Parliament and of the Council of 22 October 2014 on the deployment of alternative fuels infrastructure, Text with EEA relevance. Off. J. Eur. Union 2014, L307, 1-20.

44. European Commission. Energy Union Package-A Framework Strategy for a Resilient Energy Union with a Forward-Looking Climate Change Policy; COM/2015/080 Final; European Commission: Brussels, Belgium, 2015.

45. European Commission. Towards an Integrated Strategic Energy Technology (SET) Plan: Accelerating the European Energy System Transformation; C/2015/6317 Final; European Commission: Brussels, Belgium, 2015.

46. European Commission. A European Strategy for Low-Emission Mobility; COM/2016/0501 Final; European Commission: Brussels, Belgium, 2016. 
47. European Commission. Accelerating Clean Energy Innovation; COM/2016/0763 Final; European Commission: Brussels, Belgium, 2016.

48. European Commission. Towards Clean, Competitive and Connected Mobility: the Contribution of Transport Research and Innovation to the Mobility Package; SWD/2017/0223 Final; European Commission: Brussels, Belgium, 2017.

49. European Commission. A Clean Planet for all A European Strategic Long-Term Vision for a Prosperous, Modern, Competitive and Climate Neutral Economy; COM/2018/773 Final; European Commission: Brussels, Belgium, 2018.

50. Hardman, S.; Tal, G.; Turrentine, T.; Axsen, J.; Beard, G.; Daina, N.; Figenbaum, E.; Jakobsson, N.; Jenn, A.; Jochem, P.; et al. Driving the Market for Plug-in Vehicles: Developing Charging Infrastructure for Consumers, Policy Guide; International EV Policy Council, Plug-in Hybrid \& Electric Vehicle Research Center, University of California: Davis, CA, USA, 2018.

51. ACEA. ACEA Tax Guide 2018; ACEA-European Automobile Manufacturers Association: Brussels, Belgium, 2018.

52. German, R.; Pridmore, A.; Ahlgren, C.; Williamson, T.; Nijland, H. Vehicle Emissions and Impacts of Taxes and Incentives in the Evolution of Past Emissions EIONET Report - ETC/ACM 2018/1; ETC/ACM: Bilthoven, The Netherlands, 2018.

53. Office for Low Emission Vehicles. Tax Benefits for Ultra Low Emission Vehicles, Version 6.1. Available online: https://assets.publishing.service.gov.uk/government/uploads/system/uploads/attachment_data/file/ 709655/ultra-low-emission-vehicles-tax-benefits.pdf (accessed on 19 June 2019).

54. Bauer Consumer Media Ltd. Your Complete Guide to BIK Tax. Available online: https:/www.parkers.co.uk/ company-cars/what-is-bik/ (accessed on 19 June 2019).

55. Go Ultra Low Tax Benefits. Available online: https://www.goultralow.com/company-cars-and-fleet-vehicles/ tax-benefits/ (accessed on 19 June 2019).

56. European Commission. Staff Working Document_Detailed Assessment of the National Policy Framezorks; SWD (2017) 365; European Commission: Brussels, Belgium, 2017.

57. European Alternative Fuels Observatory European Alternative Fuels Observatory. Available online: http://www.eafo.eu/ (accessed on 19 June 2019).

58. European Commission. Staff Working Document-Report on the Assessment of the Member States National Policy Frameworks for the Development of the Market as Regards Alternative Fuels in the Transport Sector and the Deployment of the Relevant Infrastructure Pursuant to Article; Article 10 (2) of Directive 2014/94/EU-SWD(2019) 29 Final; European Commission: Brussels, Belgium, 2019.

59. Figenbaum, E.; Kolbenstvedt, M. Pathways to Electromobility-Perspectives Based on Norwegian Experiences; Institute of Transport Economics (TØI): Oslo, Norway, 2015.

60. International Energy Agency. Nordic EV Outlook 2018-Insights from Leaders in Electric Mobility; IEA: Paris, France, 2018.

61. Iceland Magazine. Government Unveils Steps to Combat Climate Change: Vehicles using Fossil Fuels Banned in 2030. Available online: https://icelandmag.is/article/government-unveils-steps-combat-climatechange-vehicles-using-fossil-fuels-banned-2030 (accessed on 27 June 2019).

62. Confédération Suisse-DETEC. Feuille de Route Pour la Mobilité Électrique 2022; Confédération Suisse-DETEC: Bern, Switzerland, 2018.

63. Incentives for Cleaner Vehicles in Urban Europe (I-CVUE). Available online: https://ec.europa.eu/energy/ intelligent/projects/en/printpdf/projects/i-cvue (accessed on 19 June 2019).

64. Murray, J. Bonus Depreciation and How It Affects Business Taxes. Available online: https://www. thebalancesmb.com/what-is-bonus-depreciation-398144 (accessed on 19 June 2019).

(C) 2019 by the authors. Licensee MDPI, Basel, Switzerland. This article is an open access article distributed under the terms and conditions of the Creative Commons Attribution (CC BY) license (http://creativecommons.org/licenses/by/4.0/). 